\title{
POSITION
}

\section{SMUKKE, RÅ OG BESKIDTE}

Data som antropologisk anliggende

\section{KLAUS HØYER OG BRIT ROSS WINTHEREIK}

Data er i dag et socialt og kulturelt anliggende, som ikke er til at komme uden om for antropologer. Vi lever i et univers af data, et „datavers“, hvor vores kroppe og identitet i utallige sammenhænge gøres til data (Bowker 2013). Dataficering har forandret økonomien (Zuboff 2019) og medierer nu også de politiske relationer, som antropologer altid har interesseret sig for. Borgeres relation til myndighederne medieres således gennem dataanalyser, der bygger på borgernes digitale spor på en måde, så borgerskabet af myndighederne kort og godt opfattes som et digitalt borgerskab (Schou \& Pors 2018). Brugen af smartphones i intimsfæren og computermedieret arbejde i det professionelle liv har skabt en konstant mulighed for at analysere og evaluere ellers flygtige handlinger. Løbende opsamling af data har gjort det muligt at forbinde rum, begivenheder og mennesker som datapunkter, selvom de ellers ikke var relaterede (Ruckenstein \& Schüll 2017). Data skaber således nye former for „thin description“, og disse repræsentationer forandrer den måde, mennesker orienterer sig på, og dermed det, som antropologer før forbandt med „thick description“ (Porter 2012). Data er måske nok på mange måder „tynde“ repræsentationer, men de rører ved alt, der er ,tykt" eller meningsmættet i menneskers liv - deres identitet, deres relationer, deres rettigheder, deres stemme og anerkendelse. Data gennemsyrer kort sagt det hverdagsliv og de politiske processer, strukturer og betydningsskabelser, som antropologer altid har interesseret sig for. Der er ingen vej uden om at interessere sig for data.

Samtidig med at data forandrer de situationer og processer, antropologer traditionelt undersøger, har antropologien også fået en forskningsinteresse i selve betingelserne for produktionen og brugen af data. Dataficeringen er i al dens mangfoldighed således ved at blive et antropologisk objekt - en genstand for teoridannelse ligesom klassiske emner som slægtskab, ritualer og gaver, der også handlede om det sociale livs cement. Hvad gør det ved politiske processer, at de skal være „datadrevne“, og hvordan forandrer det hverdagslivet, at det doku- 
menteres og monitoreres? Den gryende antropologiske interesse for dataintensivering har især fokuseret på kvantificerbare data og har i høj grad forholdt sig skeptisk til, hvad der ses som et generelt samfundsmæssigt knæfald for numeriske data som en ny ressource (Adams 2016; Biruk 2018; Erikson 2016; Hunt et al. 2017; Hutchinson et al. 2018; Merry 2016; Storeng \& Behage 2017; Sullivan 2017). Sally Engle Merry beskriver således i bogen Seductions of Quantification, hvordan der skabes en ,aura af objektivitet“ gennem data. Hun analyserer det politiske arbejde, som dette forførende skin af objektivitet gør for magtens aktører og institutioner. Ligesom flere andre (se fx Adams 2016; Biruk 2018) taler hun om behovet for, at etnografi korrigerer databaserede repræsentationer og leverer det, som data ikke kan. For eksempel skriver hun: ,The narrative ethnographic account provides an important complement to quantification" (Merry 2016: 222), og hun fremhæver vigtigheden af narrativer med ,the failure to count the unfamiliar or hard to quantify (...) banishes it to the world of the unnoticed and the disappeared" (op.cit.219).

Det er en smuk ambition og en vigtig opgave for kvalitativt trænede antropologer i en tidsalder, der på mange måder har overgivet sig til en kvantitativ forståelsesramme - men det er også en forståelse af data, som antager, at etnografiske narrativer er gode, fordi de kan illustrere og bearbejde kompleksitet, mens kvantitative data er utilstrækkelige og ikke formidler kompleksitet, men skærer den væk. Men er det en passende beskrivelse? Giver kvantitative data aldrig indsigt i kompleksitet, som kvalitative data overser? Er det ikke at se bort fra oversættelsesarbejdet $i$ alle former for dataarbejde (Ballestero \& Winthereik under udgivelse)? Tjener etnografiske narrativer og de kvalitative data, der har formet dem, altid som en form for modmagt, mens Big Data og de ,tynde beskrivelser" tjener big business og det etablerede systems interesse? Er relationen til magt og modmagt så enkel, som den gængse antropologiske narrative kritik af kvantitative data lægger op til?

Med denne position ${ }^{1}$ vil vi argumentere for større symmetri i tilgangen til digitale data og etnografiske narrativer. Både dataanalyse og etnografiske narrativer er del af vidensformer, som kan levere smukke indsigter i nogle sammenhænge og gøre beskidt politisk arbejde i andre. Begge er dele af magtkonstellationer og rummer potentiale for modmagt, og begge opererer med tvivlsomme ideer om råhed og renhed. Antropologien er ikke kun en ekstern observatør af data og dataficering, men selv en dataproducent og en dataforbruger. Af den grund skal også antropologens egne dataformodninger og teknologier til dataanalyse gøres til genstand for samme refleksioner som de formodninger, der præger de felter, antropologer studerer. Det er ikke kun de andre, der higer efter mere og bedre data. Vi er selv datamonstre. 
$\mathrm{Vi}$, forfatterne af denne position, er begge ledere af projekter, der studerer forskellige ambitioner om at gøre den offentlige service mere „datadrevet". Brit Winthereik ser på arbejdet med at bringe data i spil i en kommunal forvaltning og er blandt andet optaget af, hvordan forskellige paradigmer om data og datas rolle i den kommunale organisation finder fodfæste. Klaus Høyer har gennem nogle år studeret infrastrukturer for sundhedsdata og ambitionen om at skabe mere data af bedre kvalitet på flere mennesker og samtidig gøre disse data tilgængelige for stadigt flere formål.

I arbejdet med at interviewe politikere og særligt de administrativt ansvarlige for udformningen af mange initiativer har Klaus igen og igen hørt beslutningstagere fortælle et narrativ om en Nettopose. Nettoposen figurerede øjensynligt $i$ en lille film produceret af antropologer som del af en konsulentopgave for myndighederne, der skulle afklare patientperspektiver på datasamkøring. Klaus har aldrig set filmen, men historien går, at der i filmen var en pårørende, som havde fyldt en Nettopose med medicin og sagt, at så kunne lægerne selv se, hvad der var. Narrativet blev brugt til at forklare behovet for nye digitale løsninger på datasamkøring. Receptdata har faktisk i mange år har været digitale, men ,digital“ er ikke det samme som „let at finde“. Det interessante er, at narrativet om Nettoposen legitimerede digital datasamkøring som metode til formidling af receptdata til sundhedsprofessionelle, selvom posen som materiel og lettilgængelig løsning jo sådan set syntes at have klaret problemet allerede. Narrativet kommunikerer imidlertid ikke bare et behov for datasamkøring - det fungerer også som moralsk retningsgiver. Det allokerer ret og pligt (Frank 2012). Nettohistorien kommunikerer nemlig forestillinger om roller: Det er urimeligt, at patienten selv skal huske, hvilken medicin vedkommende tager. Det er sundhedsvæsenets ansvar, må vi forstå, når vi hører denne historie. Men når det er sundhedsvæsenets ansvar, har det også ret til at bestemme, hvem der skal have adgang til hvilke data hvornår. Narrativet har på den måde politiske implikationer. Den politiske investering $\mathrm{i}$ ambitionen om et „datadrevet sundhedsvæsen“ legitimeres altså gennem narrativer, og antropologer bidrager til at skabe disse narrativer og give dem tyngde gennem en særlig form for etnografisk autoritet: „Det er rigtige mennesker, der har det sådan“ (læg mærke til, at det ikke er en Irmapose).

Eksemplet med Nettoposen viser, at etnografiske narrativer kan være med til at legitimere digitale magtformer og altså ikke altid blot sætter ord på det, som digitale, numeriske data ikke fanger, som mange antropologer ellers lægger vægt på (Merry 2016). Det gælder nemlig for både narrativer og dataficeringsprocesser, at de i nogle tilfælde legitimerer og i andre udfordrer magten - at de nogle gange er redskaber for magtudøvelse og andre gange skaber indsigter, der fungerer som modstandsform. Det ligger ikke i metode eller udtryk, hvilket poli- 
tisk projekt repræsentationsformen er del af. Denne ambivalens er del af det teorihistoriske tankegods i samfundsvidenskaberne - fra den vending, der med inspiration i folk som Michel Foucault og Jean-François Lyotard gjorde information og diskurs til genstand for analyse (som modvægt til marxistisk materialisme), til den vending, der med inspiration i Bruno Latour og Tim Ingold gjorde materialitet og teknologi til genstand for analyse (som modvægt til det poststrukturalistiske fokus på diskurs). Derfor kan en antropologisk analyse heller ikke tage effekten for givet af hverken data eller narrativer eller alliere sig med blot én metodisk eller analytisk tradition. Digitale data og narrativer fungerer på forskellige måder, og analysen af dem kræver forskellige tiltag, men pointen her er, at hverken magtens eller modmagtens former kan forudsættes, og enhver analyse må derfor eksperimentere med sine egne greb i samspil med feltets greb for at opdage noget nyt. En symmetrisk tilgang til data og narrativer handler ikke om, at de to repræsentationsformer er ens. De er både ens og forskellige, men hvorledes deres ligheder og forskelle udmønter sig, må undersøges i praksis. Vi mener desuden, at der er behov for metodiske og analytiske eksperimenter og lyst til at arbejde refleksivt med både feltets og vores egne ideer om, hvad gode data er (Douglas-Jones et al. 2018).

Hvad er data overhovedet? Og hvordan forandrer dataficeringen vores forestillinger om det gode etnografiske narrativ? Den voksende antropologiske kritik af data lægger mest vægt på, hvad data ikke er og ikke kan - alt det, data ikke fanger. Tricia Wang gjorde for eksempel antropologer opmærksom på at „Big data needs thick data" og satte dermed et tydeligt skel mellem Big Data som et talfænomen og thick data som omhandlende narrativer (Wang 2013). Wang kritiserede Big Data-fortaleres forestillinger om at kunne få data på alt og understregede styrken i antropologiens evne til at sætte data i kontekst: „Big data delivers numbers, thick data delivers stories. “Hvad er så antropologens egen opfattelse af data? Det er langtfra alle antropologer, der taler om „data“. Nogle mener slet ikke, at antropologer har data, men foretrækker at referere direkte til feltnoter eller indsamlede artefakter uden at behøve et samlebegreb for det. For os er der ingen tvivl om, at etnografisk materiale i alle dets former er data for antropologen. Når det så er sagt, vil vi gerne nuancere, hvad der kendetegner etnografiske data.

Etnografiske data er også blevet udvalgt og oversat ind i en sammenhæng. De er formet af antagelser og tilfældigheder og medieret af forskellige praktiske omstændigheder og infrastrukturer, herunder begreber, teoriretninger og politiske projekter af forskellig art. Der findes ikke rå data (Dourish \& Cruz 2018; Gitelman 2013), heller ikke for antropologen. Der er menneskeligt arbejde i skabelsen al data. Det er et arbejde, som ofte usynliggøres i forbindelse med kun- 
stig intelligens og machine learning, og det skal vi ikke være blinde for. Men skjuler antropologer ikke også ofte, hvordan etnografiske data er blevet skabt? Selvom mange antropologer fremhæver vigtigheden af transparens i, hvor data kommer fra, skjuler et etnografisk narrativ også visse ting. Et narrativ bygger på udeladelser såvel som tilvalg, og feltnoternes narrative form, individualiseret opbevaring af datamateriale, etnografens begrebsmæssige bagage og politiske præferencer inkluderer og frasorterer også en masse materiale. Måske kan indblik $\mathrm{i}$ andres datafiktioner hjælpe med at udfordre og denaturalisere antropologers selektioner, metoder og præsentationer. En symmetrisk tilgang til kvantitative data og narrativer vil vise, at begge repræsentationsformer kan bidrage til smukke indsigter såvel som gøre „,beskidt“ politisk arbejde. Når antropologien udvikler sit teoretiske engagement med data, bliver det altså vigtigt ikke at stille sig på narrativernes side $\mathrm{i}$ en kamp mod de kvantitative data, men netop tilgå data og narrativer symmetrisk. En fremvoksende antropologisk teoridannelse om data må således ikke blive en forsimplet kritik af andre traditioners fejl. Der har hele tiden været antropologer, der har set muligheder i at bruge digitale, kvantificerbare data til antropologisk arbejde (Seaver 2015), og der er antropologer, som engageret arbejder med at udforske data med en klar bevidsthed om deres moralske og politiske ambivalens (Ruckenstein \& Schüll 2017). Det er der brug for, fordi det er de mange forskelligartede sammenhænge mellem data og narrativer, der er kernen i data som et antropologisk anliggende.

\section{Note}

1. Denne position er baseret på vores fælles velkomsttale til konferencen Big Data and the Power of Narrative afholdt den 20.-21. marts 2019 på IT-Universitetet, København, hvor 160 personer var samlet for at diskutere antropologiens forhold til data.

\section{Litteratur}

Adams, Vincanne

2016 Introduction. In: V. Adams (ed.): Metrics. What Counts in Global Health. Pp. 1-17. Durham: Duke University Press. DOI: 10.1215/9780822374480-001.

Ballestero, Andrea \& Brit Ross Winthereik

Under udgivelse The Ethnographic Effect. A Companion in Analysis. Durham: Duke University Press.

Biruk, Crystal

2018 Cooking Data. Culture and Politics in an African Research World. Durham: Duke University Press. DOI: 10.1215/9780822371823. 
Bowker, Geoffrey C.

2013 Data Flakes. In: L. Gitelman (ed.): "Raw Data" is an Oxymoron. Pp. 167-72.

Cambridge, MA: MIT Press.

Douglas-Jones, Rachel, John M. Burnett, Marisa Cohn, Christopher Gad, Michael Hockenhull, Bastian Jørgensen \& Brit Ross Winthereik

2018 A Bestiary of Digital Monsters. Paper præsenteret på the IFIP - International Federation for Information Processing, San Francisco. DOI: 10.1007/978-3-03004091-8 13 .

Dourish, Paul \& Edgar Gómez Cruz

2018 Datafication and Data Fiction. Narrating Data and Narrating with Data. Big Data \& Society:1-10. DOI: 10.1177/2053951718784083.

Erikson, Susan L.

2016 Metrics and Market Logics of Global Health. In: V. Adams (ed.): Metrics. What Counts in Global Health. Pp. 147-62. Durham: Duke University Press. DOI: 10.1215/9780822374480-001.

Frank, Arthur W.

2012 Letting Stories Breathe. A Socio-Narratology. Chicago: The University of Chicago Press.

Gitelman, Lisa

2013 "Raw Data" is an Oxymoron. Cambridge, MA: MIT Press.

Halpern, Orit

2014 Beautiful Data. A History of Vision and Reason since 1945. Durham \& London: Duke University Press. DOI: 10.1215/9780822376323

Hunt, Lisa M., Hannah S. Bell, Allison M. Baker \& Heather A. Howard

2017 Electronic Health Records and the Disappearing Patient. Medical Anthropology Quarterly 31(3):403-21. DOI: 10.1111/maq.12375.

Hutchinson, Ellinor, Susan Nayiga, Christine Nabirye, Lilian Taaka \& Sarah G. Staedke

2018 Data Value and Care Value in the Practice of Health Systems. A Case Study in Uganda. Social Science \& Medicine 211:123-30. DOI: 10.1016/ j.socscimed.2018.05.039.

Merry, Sally Engle

2016 The Seductions of Quantification. Measuring Human Rights, Gender Violence, and Sex Trafficking. Chicago: University of Chicago Press. DOI: 10.7208/chicago/ 9780226261317.001 .0001 .

Porter, Theodore M.

2012 Thin Description. Surface and Depth in Science and Science Studies. OSIRIS 27:

209-26. DOI: 10.1086/667828.

Ruckenstein, Minna \& Natasha Dow Schüll

2017 The Datafication of Health. Annual Review of Anthropology 46:261-78. DOI: 10.1146/annurev-anthro-102116-041244.

Schou, Jannick \& Anja Svejgaard Pors

2018 Digital by Default? A Qualitative Study of Exclusion in Digitalised Welfare. Social Policy Admin:1-14. DOI: 10.1111/spol.12470. 
Seaver, Nick

2015 Bastard Algebra. In: M. Engelke (ed.): Data, Now Bigger and Better! Pp. 27-47. Chicago: Prickly Paradigm.

Storeng, Katerini T. \& Dominique P. Behage

2017 "Guilty until Proven Innocent": The Contested Use of Maternal Mortality Indicators in Global Health. Critical Public Health 27(2):163-76. DOI: 10.1080/ 09581596.2016 .1259459 .

Sullivan, Noelle

2017 Multiple Accountabilities. Development Cooperation, Transparency, and the Politics of Unknowing in Tanzania's Health Sector. Critical Public Health 27(2): 193-204. DOI: 10.1080/09581596.2016.1264572.

Wang, Tricia

2013 Big Data Needs Thick Data. Hentet fra http://ethnographymatters.net/blog/2013/ 05/13/big-data-needs-thick-data/.

Zuboff, Shoshanna

2019 The Age of Surveillance Capitalism. The Fight for a Human Future at the New Frontier of Power. New York: PublicAffairs. 
